\title{
First Records of Atlantic Mackerel (Scomber scombrus) from the Svalbard Archipelago, Norway, with Possible Explanations for the Extension of Its Distribution
}

\author{
Jørgen Berge, ${ }^{1,2,3}$ Kristin Heggland, ${ }^{1,2}$ Ole Jørgen Lønne, ${ }^{1}$ Finlo Cottier, ${ }^{4}$ Haakon Hop, ${ }^{5}$ \\ Geir Wing Gabrielsen, ${ }^{1,5}$ Leif Nøttestad ${ }^{6}$ and Ole Arve Misund ${ }^{1,6}$
}

(Received 4 April 2014; accepted in revised form 19 June 2014)

\begin{abstract}
Atlantic mackerel (Scomber scombrus) were recorded in Isfjorden, Svalbard $\left(78^{\circ} 15^{\prime} \mathrm{N}, 15^{\circ} 11^{\prime} \mathrm{E}\right)$ in late September 2013. This record is the northernmost known occurrence of mackerel in the Arctic and represents a possible northward expansion (of ca. $5^{\circ}$ latitude) of its distributional range. The examined specimens of mackerel were between 7 and 11 years old, with a mean size of $39 \mathrm{~cm}$ and a mean weight of $0.5 \mathrm{~kg}$. Examination of stomach contents indicated that the mackerel were feeding mainly on juvenile herring (Clupea harengus). The occurrence of mackerel in the Arctic is discussed in relation to the recent increase in mackerel population size in the North Atlantic and the expansion of other North Atlantic fishes into the Svalbard region during the last decade. Using a decadal record of water temperature, we conclude that the occurrence of Atlantic mackerel in Svalbard waters is a result of a continued warming of the ocean in the region and that it follows a general trend of species' extending their distributional ranges northward into the Arctic.
\end{abstract}

Key words: Arctic; Atlantic mackerel; Scomber scombrus; species distribution; oceanography

RÉSUMÉ. À la fin de septembre 2013, la présence de grands maquereaux (Scomber scombrus) a été enregistrée à Isfjorden, dans l'archipel du Svalbard $\left(78^{\circ} 15^{\prime} \mathrm{N}, 15^{\circ} 11^{\prime} \mathrm{E}\right)$. Il s'agit de l'apparition de maquereaux la plus nordique à avoir été enregistrée dans l'Arctique, ce qui pourrait représenter une extension vers le nord (d'environ 5 degrés de latitude) de la répartition de cette espèce. Les individus qui ont été examinés étaient âgés de 7 à 11 ans, avaient une taille moyenne de $39 \mathrm{~cm}$ et un poids moyen de $0,5 \mathrm{~kg}$. L'analyse des contenus stomacaux a permis de déterminer que les maquereaux se nourrissaient essentiellement de harengs juvéniles (Clupea harengus). La présence du maquereau dans l'Arctique est discutée à la lumière de l'augmentation récente de la population dans l'Atlantique Nord et de l'afflux d'autres poissons de l'Atlantique Nord dans la région du Svalbard au cours de la dernière décennie. Grâce à l'enregistrement décennal de la température de l'eau, nous concluons que la présence du grand maquereau dans les eaux du Svalbard résulte du réchauffement continu de l'océan dans la région et que cela suit la tendance générale des espèces à étendre leur parcours vers le nord, dans l’Arctique.

Mots clés : Arctique; grand maquereau; Scomber scombrus; répartition des espèces; océanographie

Révisé pour la revue Arctic par Nicole Giguère.

РЕЗЮМЕ. В конце сентября 2013 года в Исфьорде, архипелаг Свальбард (78¹5' с.ш., 15¹1' в.д.), было зарегистрировано самое северное появление атлантической скумбрии (Scomber scombrus). Эта находка представляет расширение района встречаемости этого вида на примерно $5^{\circ}$ широты в северном направлении. Возраст всех обнаруженных экземпляров скумбрии составлял от 7 до 11 лет, средний размер 39 см и средний вес около 0,5 кг. Исследование содержимого желудков пойманных экземпляров показало, что скумбрия питалась в основном молодью сельди (Clupea harengus). Появление атлантической скумбрии в районе Свальбарда обсуждается в связи с увеличением численности популяции этого вида в Северной Атлантике и расширением ареалов североатлантических видов рыб в район Свальбарда в течение последнего десятилетия. На основе анализа декадных наблюдений за температурой воды в исследованном районе сделан вывод о том, что появление атлантической скумбрии в водах Свальбарда является результатом продолжающегося повышения температуры воды в регионе и отражает общую тенденцию смещения границ ареалов видов умеренных широт в северном направлении.

Ключевые слова: Арктика; атлантическая скумбрия; Scomber scombrus; распределение видов; океанография

\footnotetext{
${ }^{1}$ University Centre in Svalbard, 9171 Longyearbyen, Norway

${ }^{2}$ Faculty of Biosciences, Fisheries and Economics, UiT The Arctic University of Norway, 9037 Tromsø, Norway

${ }^{3}$ Corresponding author: jorgen.berge@uit.no

${ }^{4}$ Scottish Association for Marine Science, Scottish Marine Institute, Oban, Argyll PA37 1QA, Scotland, United Kingdom

${ }^{5}$ Norwegian Polar Institute, Fram Centre, 9296 Tromsø, Norway

${ }^{6}$ Institute of Marine Research, Box 1870, 5817 Bergen, Norway

(C) The Arctic Institute of North America
} 


\section{INTRODUCTION}

In recent years, the Atlantic mackerel (Scomber scombrus L.; hereafter, mackerel) in the North East Atlantic (NEA) has extended its distribution and migration patterns (ICES, 2013a). Normally, after spawning west of the British Isles during spring or early summer, the mackerel migrates northward to feed in the Norwegian Sea, along the Norwegian Coast, and partly in the North Sea before returning to the spawning areas in late autumn (Iversen, 2004; Fig. 1). In recent years, mackerel have been recorded and fished commercially around the Faroe Islands and Iceland, and have even been caught in the waters east of Greenland (ICES, 2013b). This northward and westward expansion of mackerel distribution appears to be related to increasing sea surface temperatures in the NEA during summer, exemplified by the warming of Atlantic water in two west Spitsbergen (Svalbard) fjords during the 1900s (Pavlov et al., 2013). However, there are also signs of an increased abundance of mackerel in general, with record high year-classes during the last 10 years (ICES, 2013a, b).

The mackerel is a relatively long-lived species, reaching a maximum age of around 20 years (Pethon, 2005). For at least the last decade, the population of the Atlantic mackerel has been quite stable, with a spawning stock of about two to four million tonnes (Bakketeig et al., 2013), but with indications of an increase of about $30 \%$ to nearly six million tonnes during the last years (ICES, 2013a). A remarkably stable recruitment and a good surplus production in the stock have yielded catches of about 500000 to 700000 tonnes annually (ICES, 2013a) and around 900000 tonnes annually during the last few years. The International Council for the Exploration of the Sea (ICES) has recommended catches of about 650000 tonnes annually, but possible overfishing due to illegal, unreported, and unregulated fishing has been a controversial issue in the management of the stock and was considered a problem until the years 2000-05 (ICES, 2013b). In recent years, the expansion in distribution has enabled Iceland and Greenland to engage in fishing of mackerel. Historically, these countries did not have a quota according to the management agreement between the coastal states that have been harvesting the mackerel stock in the NEA. As a result the management agreement was broken, and in the years 2010-13 there was no international agreement on fishing of mackerel. The European Union, Faroe Islands, and Norway recently agreed on a total allowable catch (TAC) with respective allocations of mackerel in the NEA, but Iceland is still not part of the new agreement (Anon., 2014).

In the autumn of 2013, a potential new chapter in the evolving history of mackerel in the NEA began with the first record of the species in the Arctic waters of Svalbard (Aaserud, 2013, and this study). We followed up this unexpected occurrence of mackerel in the Arctic with a small survey near Longyearbyen, adding a description of related oceanographic conditions of the sea in the area. Our aims with this study were to evaluate the magnitude of the

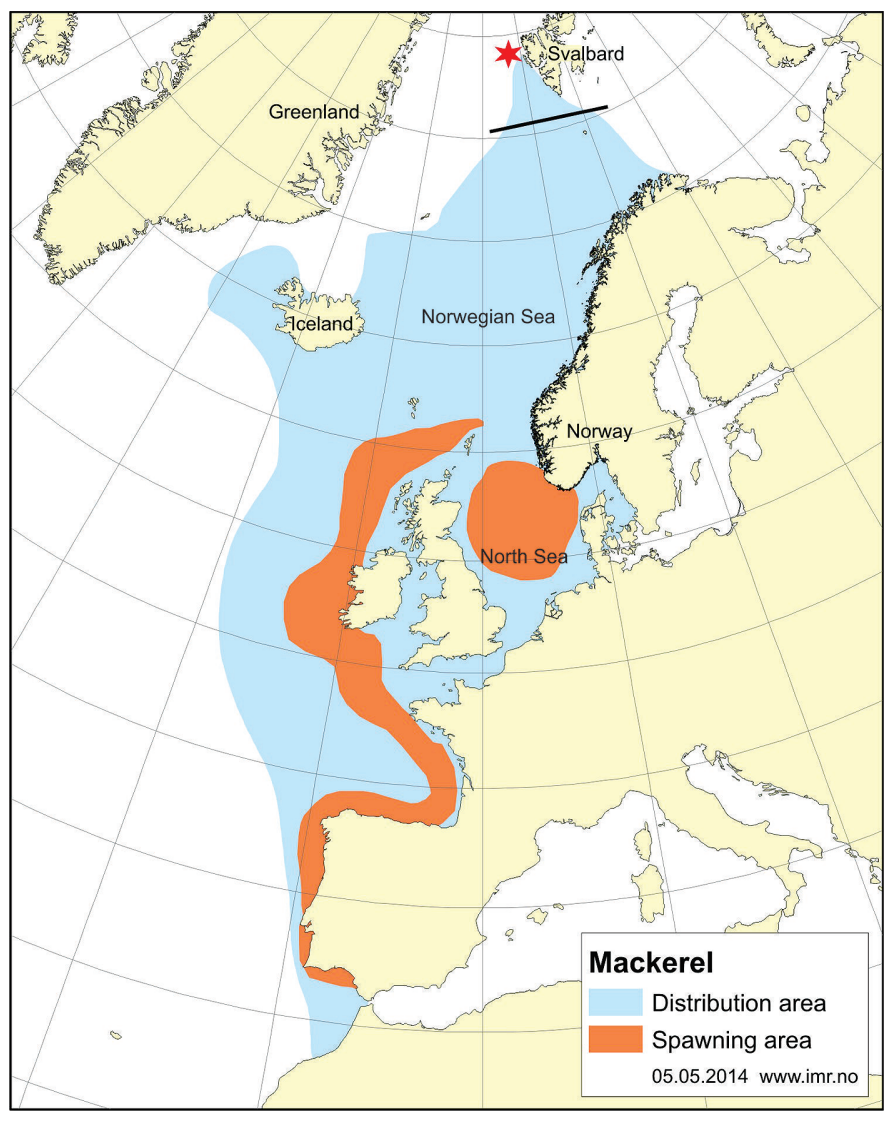

FIG. 1. Distribution of Atlantic mackerel (blue area). The red star indicates the Isfjorden and Kongsfjorden areas of Svalbard. The black line shows the previous northern distribution limit, and orange indicates known spawning areas.

mackerel influx into Isfjorden and to characterize basic biological traits of the individuals collected.

\section{MATERIAL AND METHODS}

Fish data for this study were collected from Isfjorden $\left(78^{\circ} 15^{\prime} \mathrm{N}, 15^{\circ} 11^{\prime} \mathrm{E}\right)$, a west-facing fjord in the Svalbard archipelago (Fig. 1). Six mackerel were collected with hook and line from the RV Viking Explorer on 22-23 September 2013. An additional four mackerel caught by local residents during this period were included in the study. Scientific bottom and pelagic trawling and hook-and-line fishing in the fjord from the RV Helmer Hanssen on 24-25 September 2013 caught no mackerel. During the collection period, water temperature in the upper $40 \mathrm{~m}$ of the water column, measured with a profiling CTD rosette, ranged from $5.0^{\circ} \mathrm{C}$ to $5.5^{\circ} \mathrm{C}$.

Fish caught from RV Viking Explorer were identified according to Pethon (2005) and frozen whole. After thawing in the lab, total length $(\mathrm{cm})$ and total wet weight $(\mathrm{g})$ were measured. Otoliths were removed and ages estimated from them by experts at the Institute of Marine Research in Bergen, Norway, according to their standard procedures for age determination of the species (Mjanger et al., 2013). Sex 
of individual specimens was determined through morphological examination of their gonads. The gonadal somatic index (GSI) was determined from the gonadal weight as a percentage of carcass weight (gonads and stomach contents subtracted from total weight). Guts were removed and stomach contents were weighed and recorded. Stomach contents were identified to the lowest possible taxon under a stereomicroscope.

To investigate interannual variation in the local oceanographic conditions, we used hydrographic data collected since 2002 by oceanographic moorings in Kongsfjorden (Fig. 1) since ocean dynamics and conditions in the adjacent fjords of Kongsfjorden and Isfjorden are known to be similar (Nilsen et al., 2008; Pavlov et al., 2013). These moorings, which have recorded the seasonal variability in ocean conditions in this region (e.g., Cottier et al., 2005, 2007), were placed in the entrance to Kongsfjorden, typically at water depths of more than $200 \mathrm{~m}$, with instrumentation spanning the water column from $20 \mathrm{~m}$ below the surface to $10 \mathrm{~m}$ from the seabed. Most mooring deployments had at least 10 temperature sensors distributed throughout the depth range (see Cottier et al., 2005 for typical mooring arrangement and instrumentation). As winter conditions are considered a precursor of subsequent summer intrusions of Atlantic water into the west-facing Svalbard fjords (Nilsen at al., 2008), we calculated the mean temperature integrated for the water column during winter (February-April). Also, since winter temperatures might play an important role in the survival of newly established populations, they are relevant to our argument concerning the gradual increase of boreal species entering the Arctic.

To test for significant shifts in winter temperature, we applied an algorithm to the resulting time-series of mean winter temperatures. The algorithm detects shifts in the data series by the sequential application of $t$-tests to determine whether each data point differs significantly in its properties from the preceding points (for details of the computation, see Rodionov, 2004). Significant changes are confirmed or rejected by considering the subsequent data points. In this way, there was no prior assignation of the shift point; rather it emerges from the statistical treatment of the data series. The cut-off length $(l)$ is an important criterion, which sets a minimum length of a period to be considered a regime, as well as the significance level $p$ of the $t$-test. In our analysis of winter temperatures, we used $l=3$ years because this length permitted better resolution of regimes occurring in a relatively short data series. The significance level for the test was set to $\alpha=0.1$. Autocorrelation of the data (deYoung et al., 2004) can introduce red noise, which can be a problem in such time series; we handled this by using a "prewhitening" technique [available at www.beringclimate.noaa.gov] that removes the red noise component through subsampling and bias correction (Rodionov, 2006).

We also document changes in the fish fauna of Kongsfjorden and Isfjorden on Svalbard over the last 15 years. Data are derived mainly from our cruises with RV Helmer
Hanssen, from which the University Centre in Svalbard has conducted regular surveys of the fish fauna every autumn since the late 1990s. This information is supplemented by observations from research cruises by UiT The Arctic University of Norway, the Norwegian Polar Institute, and published records.

\section{RESULTS}

In total, six mackerel were caught at $20-50 \mathrm{~m}$ depth during six hours of fishing on 22-23 September 2013 (Table 1). Three additional fish were hooked, but lost at sea. In addition, four individuals collected at the same time in the same area were made available to us by local inhabitants of Longyearbyen. The 10 specimens had a mean weight of $510 \pm 67.1 \mathrm{~g}$, a mean length of $38.9 \pm 1.6 \mathrm{~cm}$, and a mean age of 7+ years (Table 1). All fish were females, with GSI ranging from $0.20 \%$ to $1.50 \%$. Six taxa were present in the stomachs of the mackerel (Table 2). Fish were the main prey, present in $90 \%$ of the stomachs and constituting more than $98 \%$ of the total prey dry weight. Two of the stomachs contained only herring (Clupea harengus L.), and 41.7\% of the total consumed prey dry weight was unequivocally identified as herring. However, the texture and color of the remaining fish items $(56.4 \%$ of prey dry weight) indicate that all fish consumed were probably herring. Two of the fish had eaten squid, but this group accounted for only $1.5 \%$ of prey by weight. Crustacea (Calanus sp. and Thysanoessa sp.) were present in two of the stomachs, although it is possible that some originated from the fish eaten by the mackerel. The consumed herring had large amounts of calanoid copepods in their stomachs.

The time-series of winter mean temperatures indicated that the temperatures were below zero (mean value $=-1^{\circ} \mathrm{C}$ ) from 2002 to 2005, whereas five of eight winters had temperatures above zero (mean value $=0.5^{\circ} \mathrm{C}$ ) from 2006 onwards (Fig. 2). Using the method outlined by Rodionov $(2004,2006)$, we identified a statistically significant shift in winter temperatures in 2006 at $p=0.1$. The occurrence of a single shift in 2006 was insensitive to the use of $l=3,4$, or 5 years, demonstrating that the result is quite robust to selection of length.

\section{DISCUSSION}

The local newspaper, Svalbardposten, reported that inhabitants of Longyearbyen had collected 72 specimens, ranging between 35 and $40 \mathrm{~cm}$ long, one week earlier in the same fjord (Aaserud, 2013). These individuals were not available for examination and are therefore not included in the present study. They do, nevertheless, underline the fact that the occurrence of mackerel in Isfjorden involves more than a few single individuals. The mackerel caught by residents of Longyearbyen (Aaserud, 2013) and by the RV Viking Explorer (this study) did confirm the occurrence 
TABLE 1. Total weight (TW, g), total length (TL, cm), dry weight of stomach contents ( $\mathrm{g}$ ), wet weight of gonads (g), gender, and age (years) of 10 Atlantic mackerel collected in Isfjorden, Svalbard, on 22-23 September 2013. All individuals were mature, and the GSI was below $2 \%$ for all examined individuals (data not shown).

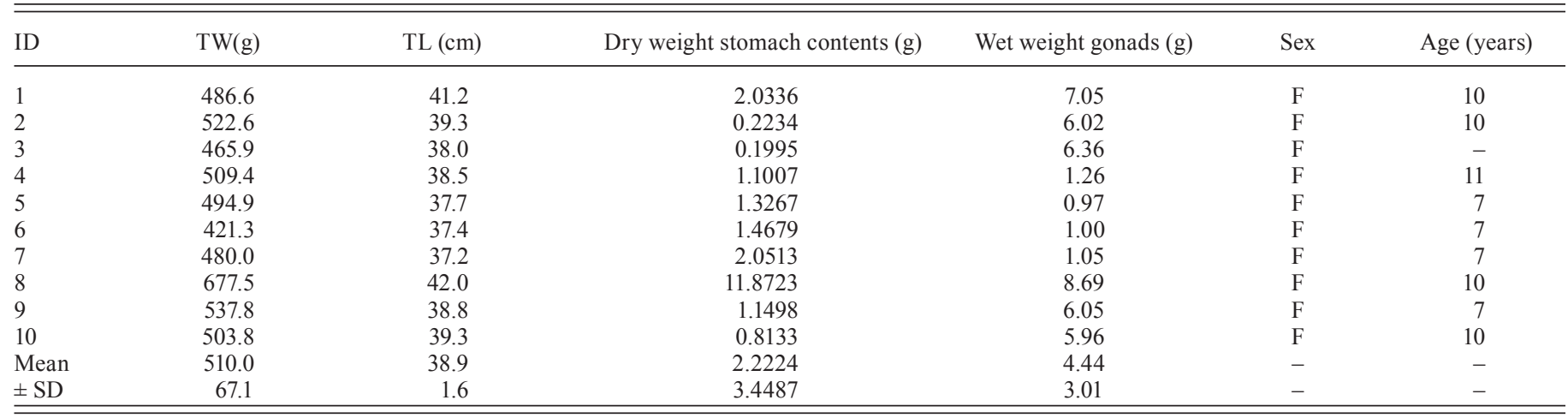

of the species in Svalbard. However, the lack of mackerel in the trawl catches from the same area by the RV Helmer Hanssen over the next few days suggested that the numbers of mackerel in the area were limited. The individuals caught in Isfjorden were between 7 and 11 years old, paralleled by the very strong year-classes in 2002, 2005, and 2006 (ICES, 2013b; Nøttestad, 2014). This age range also indicates that it is the older individuals in the populations that make such long migrations (see Nøttestad et al., 1999) beyond the limits of their hitherto normal distribution ranges. The mackerel were mature, but their low GSI $(<2 \%)$ indicated that they were not in spawning but rather in postspawning condition. The NEA mackerel is a fast swimmer: it can swim at a sustained speed of $1 \mathrm{~m} \mathrm{~s}^{-1}$ over extended periods (He and Wardle, 1988). Therefore it is possible, if the temperature range is within their tolerance limits, that these mackerel are capable of covering the distance from Tromsø, south of the previous northern edge of the species' distribution, to Longyearbyen (973 km in a straight line) within a two-week period (assuming a constant average speed). Their optimum temperature is in the $7^{\circ} \mathrm{C}-13^{\circ} \mathrm{C}$ range, and their lower tolerance at around $4.5^{\circ} \mathrm{C}$ (Iversen, 2004). An interesting observation in our study was that mackerel were found to feed more or less exclusively on juvenile herring, reinforcing the documentation that

TABLE 2. Prey occurrence and prey weight from 10 mature female Atlantic mackerel stomachs from Isfjorden, Svalbard. $\% \mathrm{~F}=$ the number of stomachs containing a specific prey item as percentage of all sampled stomachs. DW = the combined dry weight $(\mathrm{g})$ of each prey category consumed. $\% \mathrm{DW}=$ dry weight as a percentage of the total dry weight of the total stomach contents.

\begin{tabular}{llrrr}
\hline \hline Prey taxa & & $\% \mathrm{~F}$ & $\mathrm{DW}$ & $\% \mathrm{DW}$ \\
\hline Crustacea & & 20 & 0.07 & 0.3 \\
& Crustacea ind. & 10 & 0.02 & 0.1 \\
& Calanus sp. & 10 & 0.05 & 0.2 \\
Cephalopoda & Thysanoessa sp. & 10 & $<0.01$ & $<0.1$ \\
Pisces & Theutoidea & 20 & 0.34 & 1.5 \\
& & 90 & 103.12 & 98.1 \\
& Unidentified fish & 80 & 12.55 & 56.4 \\
& Clupea harengus & 20 & 9.27 & 41.7 \\
\hline \hline
\end{tabular}

mackerel can be effective predators on both larvae and juvenile herring during their active feeding migration in the Arctic (see Skaret et al., 2014, reporting from a study along the Norwegian coast).

\section{Large-scale Oceanographic Conditions and Ranges of Boreal Fishes}

Most of the world's oceans, including the North Atlantic and Arctic Oceans, have experienced pronounced variations in temperatures during the last 120000 years (Rahmstorf, 2002; Sarnthein et al., 2003). The warmer temperatures of Atlantic water entering the Arctic Ocean in the early $21^{\text {st }}$ century have no precedent in the past 2000 years and are presumably linked to the Arctic amplification

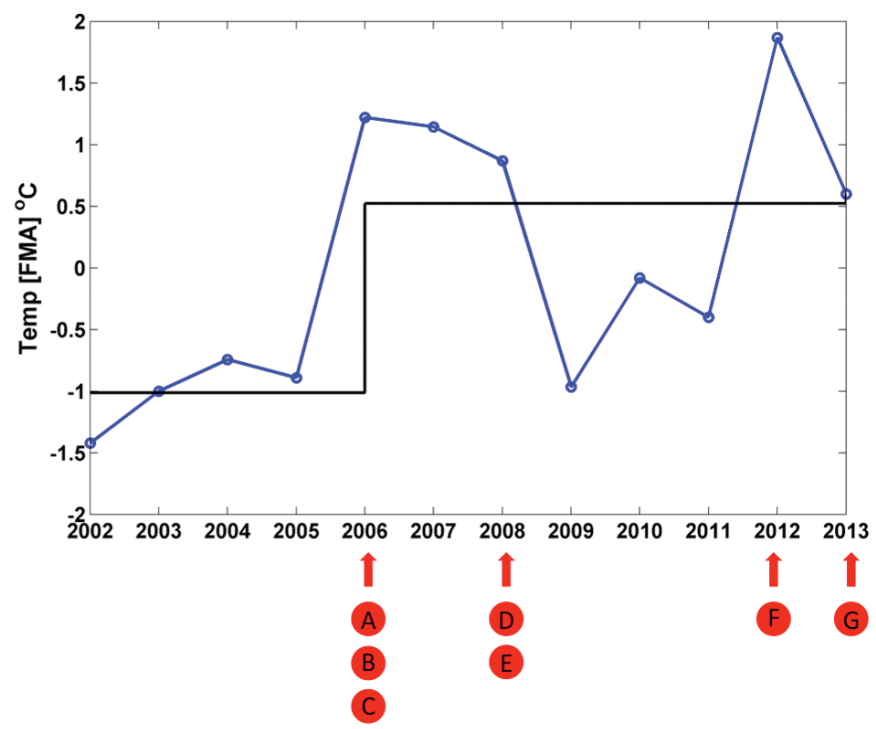

FIG. 2. New fish species in Svalbard waters in relation to ocean temperature. Points on blue line represent mean water column temperatures during winter (February-April) in each year. Black line shows significantly higher mean winter temperatures since the 2006 warming event than before $2006(p=0.1)$. All new fish species were recorded during this warmer period. Red circles below a year indicate first records in Kongsfjorden for (A): Mallotus villosus, (B): Melanogrammus aeglefinus, (C): Entelurus aequoreus, (D): Gadus morhua (juv.), (E): Melanogrammus aeglefinus (juv.), (F): Clupea harengus, and (G): Scomber scombrus. 
$58 \cdot \mathrm{J}$. BERGE et al.

TABLE 3. Changes in the Pisces fauna in Kongsfjorden and Isfjorden (Svalbard) over the last 15 years.

\begin{tabular}{ll}
\hline \hline Species & Occurrence in Svalbard \\
\hline Atlantic cod (Gadus morhua) & Caught since the mid-1990s. Adult cod have been caught regularly using a bottom trawl since the early \\
& 2000s. Juveniles $(<10 \mathrm{~cm}$ ) have appeared in catches since 2008. \\
Capelin (Mallotus villosus) & Adults have become increasingly common since 2006 (Hop and Gjøsæter, 2013). The diet of kittiwakes \\
& (Rissa tridactyla) shifted from polar cod (Boreogadus saida) to capelin in 2007. Both adults and juveniles \\
have been sampled regularly since 2010. & \\
Atlantic snake pipefish (Entelurus aequoreus) & Fecorded in Svalbard waters from August 2006 (Fleischer et al., 2007), but is not regularly occurring. \\
Atlantic herring (Clupea harengus) & Recorded in Kongsfjorden, with few individuals since 2006 (Hop and Gjøsæter, 2013). In Isfjorden, Atlantic \\
& herring were first recorded in April 2012 (adult specimens only), and juveniles have occurred regularly since \\
Atlantic mackerel (Scomber scombrus) & 2012. \\
\hline \hline
\end{tabular}

of global warming (Spielhagen et al., 2011). In the Barents and Greenland Seas, these changes are manifested through an increased volume transport of Atlantic water, which can exchange with water found on the adjacent shelves and in the fjords on the west coast of Svalbard (Cottier et al., 2005, 2007; Nilsen et al., 2008).

As the North Atlantic and Arctic Oceans and the Eurasian Arctic shelf seas are strongly linked through the North Atlantic Current System (NACS), variations in this current system are likely to have a direct and detectable influence on the marine flora and fauna in these regions (Piechura and Walczowski, 2009; Narasyanaswamy et al., 2010; Renaud et al., 2012). The main route for northward migration of boreal and temperate species is the West Spitsbergen Current (WSC). Recent work has shown that the temperature change in the WSC has been approximately $0.01^{\circ} \mathrm{C}$ per year for the last 15 years (Walczowski et al., 2012) and that the maximum temperature in the adjacent fjords has increased by around $0.02^{\circ} \mathrm{C}$ per year over the last century (Pavlov et al., 2013). This increase may be exemplified by the past and current distributions of the blue mussel (Mytilus edulis L.) in the Arctic (Berge et al., 2005) or the change in hard-bottom benthos (Kortsch et al., 2012). The presence or absence of blue mussels in Svalbard during the last 11000 years is probably linked to oscillations in ocean climate that resulted from changes in the volume transport of Atlantic water through the NACS (Berge et al., 2005, 2006). Accordingly, as the average temperature in the WSC has not increased relative to that inside the fjords of Svalbard (Cottier et al., 2005, 2007; Walczowski et al., 2012; Fig. 2), the appearance of boreal species is assumed to be linked with processes that enable these species to enter the fjord, rather than to those that allow them to reach this far north. In the discussion below, we therefore treat the mackerel as having a more or less continuous distribution within its known distributional range (see Fig. 1), although this continuity is merely an assumption and the documented distributional range is discontinuous. Nevertheless, the documented occurrence of mackerel in Svalbard fjords does illustrate the interplay between large-scale oceanographic conditions (mostly through the NACS) and more local cross-shelf exchange processes at the mouth of the fjord, both of which are essential for a temperate species to eventually enter the fjord.
Effect of Local Oceanographic Conditions on Boreal Fishes

Our oceanographic data from Kongsfjorden show a measurable change in the winter oceanic conditions during the last decade. While declaring a regime shift on the basis of winter temperature alone should be done with caution, the periods before and after 2006 are statistically different (Fig. 2). Table 3 shows that except for Atlantic cod, all new boreal fish species in Svalbard have been recorded since 2006. Previous work (Nilsen et al., 2008) has shown that winter conditions, particularly those related to sea ice formation, can modify the extent to which Atlantic water can exchange effectively with the fjord in subsequent summers.

The shift in winter temperatures in Svalbard fjords therefore has the potential to influence the fish population in two ways; directly through increased survival during winter periods or more indirectly through an increased influx of Atlantic water during summer and autumn seasons. Advection of Atlantic zooplankton species into the fjords has been demonstrated in Kongsfjorden (e.g., Willis et al., 2006, 2008). Populations of such advected organisms (those that are not active swimmers) are more likely to survive overwintering in the fjords when winter temperatures are elevated (e.g., Berge et al., 2005). Long-term changes in oceanic conditions, with enhanced winter survival through increased influx of Atlantic waters, are likely important regulating factors for new establishment of boreal species in the fjords of Svalbard (e.g., Berge et al., 2009). The occurrence of fish species in Svalbard waters seems to have increased steeply since 2006. Mackerel, however, currently appear to be present in Svalbard waters only as late summer transients.

\section{CONCLUSIONS}

In accordance with these observations, mackerel may be regarded as part of a sequence of marine temperate or boreal organisms that move northward. Many boreal fish species have recently shifted their distributions northward in response to increasing ocean temperatures and decreasing sea ice (Drinkwater, 2009; Wienerroither et al., 2011; Renaud et al., 2012; Hop and Gjøsæter, 2013; Christiansen et al., 2014; Table 3). The occurrence of mackerel reported 
here could also represent a unique observation of specimens far outside their normal distributional area, rather than an extension of mackerel distribution. However, occurrences of several new fish species in the fjord that do not seem to be related to a simple northward extension of isotherms (see Walczowski et al., 2012) indicate that both large-scale oceanographic alterations in volume transport through the NACS and advection and physical cross-shelf exchange processes are important factors for fish entry into the fjords. One might also argue that the occurrence of mackerel in the Arctic is linked to the increasing population size at lower latitudes (ICES, 2013b) and that its current northward expansion is due mainly to the size and population structure of the mackerel stock (Nøttestad, 2014). However, other comparable changes in both benthic and pelagic fauna have been detected (e.g., Beuchel et al., 2006; Greene et al., 2008; Narayanaswamy et al., 2010; Berge et al., 2012; Kwasniewski et al., 2012) and related to annual and decadal oscillations in the transport and temperature of Atlantic water (Polyakov et al., 2005; Pavlov et al., 2013). Although the causes of such changes are not fully understood, their consequences for the Arctic flora and fauna are likely substantial. The recent northward extension of the mackerel's distribution range should be interpreted in this context, not as a unique and isolated incident, but as yet another part of a domino sequence in which boreal species are established at the northernmost extension of the North Atlantic current system. It is therefore likely that even more new occurrences of boreal fish species will be observed in the Arctic. Migrating species will likely change their distribution not only in response to changes in temperature, which make it possible for them to reach other food sources in the Arctic, but also in relation to shifts in distribution of their preferred prey species (Dalpadado et al., 2012).

\section{ACKNOWLEDGEMENTS}

The authors are grateful to an anonymous local resident in Longyearbyen for delivering mackerel to us, two anonymous reviewers who helped improve the quality of the manuscript, and the captain and crew onboard the RV Helmer Hanssen and Viking Explorer. A particular thanks to Colin Griffiths for overseeing the collection of mooring data in Kongsfjorden since 2002. We thank Professor K. Kosobokova for helping with the Russian abstract. The work is partly financed by the Norwegian Research Council through the Environmental Waste Management in the Arctic Project 195160 and Circa Project 214271/F20. It is also a contribution to the Natural Environment Research Council program Oceans 2025.

\section{REFERENCES}

Aaserud, M. 2013. Pionermakrellen har kommet til Longyearbyen [The pioneer mackerel has arrived in Longyearbyen]. Svalbardposten 37:4-5.
Anon. 2014. Agreed record on a Fisheries Arrangement between the European Union, the Faroe Islands and Norway on the management of mackerel in the North-East Atlantic from 2014 to 2018 .

http:/www.regjeringen.no/pages/38649623/Makrellavtale 2014.pdf

Bakketeig, I.E., Gjøsæter, H., Hauge, M., Loeng, H., Sunnset, B.H., and Toft, K.Ø., eds. 2013. Havforskningsrapporten 2013. Fisken og Havet, Special Issue 1. 195 p.

Berge, J., Johnsen, G., Nilsen, F., Gulliksen, B., and Slagstad, D. 2005. Ocean temperature oscillations enable reappearance of blue mussels Mytilus edulis in Svalbard after a 1000 year absence. Marine Ecology Progress Series 303:167-175. http://dx.doi.org/10.3410/f.1029935.346660

Berge, J., Johnsen, G., Nilsen, F., Gulliksen, B., Slagstad, D., and Pampanin, D.M. 2006. The Mytilus edulis population in Svalbard: How and why. Marine Ecology Progress Series 309:305-306.

Berge, J., Renaud, P.E., Eiane, K., Gulliksen, B., Cottier, F.R., Varpe, Ø., and Brattegard, T. 2009. Changes in the decapod fauna of an Arctic fjord during the last 100 years (1908-2007). Polar Biology 32(7):953-961. http://dx.doi.org/10.1007/s00300-009-0594-5

Berge, J., Varpe, O., Moline, M.A., Wold, A., Renaud, P.E., Daase, M., and Falk-Petersen, S. 2012. Retention of ice-associated amphipods: Possible consequences for an ice-free Arctic Ocean. Biology Letters 8(6):1012-1015.

http://dx.doi:10.1098/rsbl.2012.0517

Beuchel, F., Gulliksen, B., and Carroll, M.L. 2006. Long-term patterns of rocky bottom macrobenthic community structure in an Arctic fjord (Kongsfjorden, Svalbard) in relation to climate variability (1980-2003). Journal of Marine Systems 63(1-2):35-48.

http://dx.doi.org/10.1016/j.jmarsys.2006.05.002

Christiansen, J.S., Mecklenburg, C.W., and Karamushko, O.V. 2014. Arctic marine fishes and their fisheries in light of global change. Global Change Biology 20(2):352-359.

http://dx.doi:10.1111/gcb.12395

Cottier, F.R., Tverberg, V., Inall, M.E., Svendsen, H., Nilsen, F., and Griffiths, C. 2005. Water mass modification in an Arctic fjord through cross-shelf exchange: The seasonal hydrography of Kongsfjorden, Svalbard. Journal of Geophysical Research 110, C12005. http://dx.doi.org/10.1029/2004jc002757

Cottier, F.R., Nilsen, F., Inall, M.E., Gerland, S., Tverberg, V., and Svendsen, H. 2007. Wintertime warming of an Arctic shelf in response to large-scale atmospheric circulation. Geophysical Research Letters 34, L10607. http://dx.doi:10.1029/2007GL029948

Dalpadado, P., Ingvaldsen, R.B., Stige, L.C., Bogstad, B., Knutsen, T., Ottesen, G., and Ellertsen, B. 2012. Climate effects on Barents Sea ecosystem dynamics. ICES Journal of Marine Science 69(7):1303-1316.

http://dx.doi.org/10.1093/icesjms/fss063

deYoung, B., Harris, R., Alheit, J., Beaugrand, G., Mantua, N., and Shannon, L. 2004. Detecting regime shifts in the ocean: Data considerations. Progress in Oceanography 60(2-4):143-164. http://dx.doi.org/10.1016/j.pocean.2004.02.017 
Drinkwater, K. 2009. Comparison of the response of Atlantic cod (Gadus morhua) in the high-latitude regions of the North Atlantic during the warm periods of the 1920s-1960s and the 1990-2000s. Deep Sea Research II 56(21-22):2087-2096. http://dx.doi.org/10.1016/j.dsr2.2008.12.001

Fleischer, D., Schaber, M., and Piepenburg, D. 2007. Atlantic pipefish (Entelurus aequoreus) extends its northward distribution range to Svalbard (Arctic Ocean). Polar Biology 30(10):1359-1362.

http://dx.doi.org/10.1007/s00300-007-0322-y

Greene, C.H., Pershing, A.J., Cronin, T.M., and Ceci, N. 2008. Arctic climate change and its impacts on the ecology of the North Atlantic. Ecology 89(11):S24-S38. http://dx.doi.org/10.1890/07-0550.1

He, P., and Wardle, C.E. 1988. Endurance at intermediate swimming speeds of Atlantic mackerel, Scomber scombrus L., herring, Clupea harengus L., and saithe, Pollachius virens L. Journal of Fish Biology 33(2):255-266. http://dx.doi.org/10.1111/j.1095-8649.1988.tb05468.x

Hop, H., and Gjøsæter, H. 2013. Polar cod (Boreogadus saida) and capelin (Mallotus villosus) as key species in marine food webs of the Arctic and the Barents Sea. Marine Biology Research 9:878-894. http://dx.doi.org/10.1080/17451000.2013.775458

ICES (International Council for the Exploration of the Sea). 2013a. Mackerel in the Northeast Atlantic (combined Southern, Western and North Sea spawning components). ICES Advice 2013, Book 9, Copenhagen.

- 2013b. Report of the Working Group on Widely Distributed Stocks (WGWIDE), 27 August-2 September 2013. ICES CM 2013/ACOM:15. Copenhagen: ICES Advisory Committee. 950 p.

Iversen, S.A. 2004. Mackerel and horse mackerel. In: Skjoldal, H.R., ed. The Norwegian Sea ecosystem. Trondheim: Tapir Academic Press. 289-300.

Kortsch, S., Primicerio, R., Beuchel, F., Renaud, P.E., Rodrigues, J., Lønne, O.J., and Gulliksen, B. 2012. Climate-driven regime shifts in Arctic marine benthos. Proceedings of the National Academy of Sciences 109(35):14052-14057.

http://dx.doi.org/10.1073/pnas.1207509109

Kwasniewski, S., Gluchowska, M., Walkusz, W., Karnovsky, N.J., Jakubas, D., Wojczulanis-Jakubas, K., Harding, A.M.A., et al. 2012. Interannual changes in zooplankton on the West Spitsbergen Shelf in relation to hydrography and their consequences for the diet of planktivorous seabirds. ICES Journal of Marine Science 69(5):890-901.

http://dx.doi.org/10.1093/icesjms/fss076

Mjanger, H., Hestenes, K., Svendsen, B.V., and Wenneck, T.D.L. 2013. Manual for sampling of fish and crustaceans, Version 3.16. Bergen: Institute of Marine Research. 199 p.

Narayanaswamy, B.E., Renaud, P.E., Duineveld, G.C.A., Berge, J., Lavaleye, M.S.S., Reiss, H., and Brattegard, T. 2010. Biodiversity trends along the western European margin. PloS One 5(12), e14295.

http://dx.doi:10.1371/journal.pone.0014295
Nilsen, F., Cottier, F.R., Skogseth, R., and Mattsson, S. 2008. Fjord-shelf exchanges controlled by ice and brine production: The interannual variation of Atlantic Water in Isfjorden, Svalbard. Continental Shelf Research 28(14):1838-1853.

http://dx.doi.org/10.1016/j.csr.2008.04.015

Nøttestad, L. 2014. Makrell - Nordøstatlantisk makrell [Mackerel Northeast Atlantic mackerel]. Havforskningsrapporten 2014. Fisken og Havet, Special Issue 1-2014. 172 p.

Nøttestad, L., Giske, J., Holst, J.C., and Huse, G. 1999. A lengthbased hypothesis to explain feeding migrations in pelagic fish. Canadian Journal of Fisheries and Aquatic Sciences 56 (S1):26-34. http://dx.doi.org/10.1139/f99-222

Pavlov, A.K., Tverberg, V., Ivanov, B.V., Nilsen, F., Falk-Petersen, S., and Granskog, M.A. 2013. Warming of Atlantic Water in two west Spitsbergen fjords over the last century (1912-2009). Polar Research 32, 11206. http://dx.doi.org/10.3402/polar.v32i0.11206

Pethon, P. 2005. Aschehougs store fiskebok [Aschehougs guide to fishes], 5th ed. Oslo: Aschehoug.

Piechura, J., and Walczowski, W. 2009. Warming of the West Spitsbergen Current and sea ice north of Svalbard. Oceanologia 51(2):147-164.

http://dx.doi.org/10.5697/oc.51-2.147

Polyakov, I.V., Bhatt, U.S., Simmons, H.L., Walsh, D., Walsh, J.E., and Zhang, X. 2005. Multidecadal variability of North Atlantic temperature and salinity during the twentieth century. Journal of Climate 18(21):4562-4581.

http://dx.doi.org/10.1175/jcli3548.1

Rahmstorf, S. 2002. Ocean circulation and climate during the past 120,000 years. Nature 419:207-214.

http://dx.doi.org/10.1038/nature01090

Renaud, P.E., Berge, J., Varpe, Ø., Lønne, O.J., Nahrgang, J., Ottesen, C., and Hallanger, I. 2012. Is the poleward expansion by Atlantic cod and haddock threatening native polar cod, Boreogadus saida? Polar Biology 35(3):401 - 412. http://dx.doi.org/10.1007/s00300-011-1085-z

Rodionov, S.N. 2004. A sequential algorithm for testing climate regime shifts. Geophysical Research Letters, 31, L09204. http://dx.doi.org/10.1029/2004g1019448

. 2006: Use of prewhitening in climate regime shift detection. Geophysical Research Letters, 33, L12707. http://dx.doi.org/10.1029/2006g1025904

Sarnthein, M., Van Kreveld, S., Erlenkeuser, H., Grootes, P.M., Kucera, M., Pflaumann, U., and Scholz, M. 2003. Centennialto-millennial-scale periodicities of Holocene climate and sediment injections off the western Barents shelf, $75^{\circ} \mathrm{N}$. Boreas 32(3):447-461. http://dx.doi.org/10.1111/j.1502-3885.2003.tb01227.x

Skaret, G., Langøy, H., Stenevik, E.K., Utne, K.R., and Slotte, A. 2014. Investigation of mackerel predation on herring larvae on the Norwegian coastal shelf. Rapport fra Havforskningen No. 6-2014. Bergen: Institute of Marine Research. 17 p. http://www.imr.no/filarkiv/2014/04/hi-rapp_6-2014_mackerel _ predation.pdf/nb-no 
Spielhagen, R.F., Werner, K., Sørensen, S.A., Zamelczyk, K., Kandiano, E., Budeus, G., Husum, K., Marchitto, T.M., and Hald, M. 2011. Enhanced modern heat transfer to the Arctic by warm Atlantic water. Science 331(6016):450-453. http://dx.doi:10.1126/science.1197397

Walczowski, W., Piechura, J., Goszczko, I., and Wieczorek, P. 2012. Changes in Atlantic water properties: An important factor in the European Arctic marine climate. ICES Journal of Marine Science 69(5):864-869.

http://dx.doi.org/10.1093/icesjms/fss068
Wienerroither, R.M., Nedreaas, K.H., Uiblein, F., Christiansen, J.S., Byrkjedal, I., and Karamushko, O. 2011. The marine fishes of Jan Mayen Island, NE Atlantic - past and present. Marine Biodiversity 41(3):395-411.

http://dx.doi.org/10.1007/s12526-010-0055-y

Willis, K.J., Cottier, F.R., Kwasniewski, S., Wold, A., and FalkPetersen, S. 2006. The influence of advection on zooplankton community composition in an Arctic fjord (Kongsfjorden, Svalbard). Journal of Marine Systems 61(1-2):39-54. http://dx.doi.org/10.1016/j.jmarsys.2005.11.013

Willis, K.J., Cottier, F.R., and Kwasniewski, S. 2008. Impact of warm water advection on the winter zooplankton community in an Arctic fjord. Polar Biology 31(4):475-481.

http:/dx.doi.org/10.1007/s00300-007-0373-0 